\title{
Commentary: Cardiac surgery, nutrition, and recovery-First define the problem
}

\author{
Kevin W. Lobdell, MD, ${ }^{a}$ and Daniel T. Engelman, $\mathrm{MD}^{\mathrm{b}}$
}

\author{
From the a Department of Cardiovascular and Thoracic Surgery, Atrium Health, Charlotte, NC; and ${ }^{\mathrm{b}}$ Heart \& \\ Vascular Program, Baystate Health, Springfield, Mass. \\ Disclosures: K.W.L. consults for Medtronic; D.T.E. consults for Edwards Lifesciences. \\ Received for publication March 22, 2019; accepted for publication March 22, 2019; available ahead of print April \\ $25,2019$. \\ Address for reprints: Daniel T. Engelman, MD, 759 Chestnut St, Springfield, MA 01199 (E-mail: Daniel \\ Engelman@baystatehealth.org). \\ J Thorac Cardiovasc Surg 2019;158:1109-10 \\ $0022-5223 / \$ 36.00$ \\ Copyright (c) 2019 by The American Association for Thoracic Surgery \\ https://doi.org/10.1016/j.jtcvs.2019.03.065
}

\begin{abstract}
If I had only one hour to save the world, I would spend fifty-five minutes defining the problem, and only five minutes finding the solution.
\end{abstract}

Enhanced Recovery After Cardiac Surgery (ERAS Cardiac) efforts emphasize the importance of a comprehensive, periprocedural, standardized process to "reduce surgical stress, maintain physiological functional capacity, and facilitate postoperative recovery through evidence-based best practice." ${ }^{1}$ Enhanced recovery efforts suggest that cardiac surgeons have the opportunity to create protocols that may significantly affect our patients. As an example, planning a patient's procedure should routinely involve an assessment of risk that includes measurements of frailty, anemia, hyperglycemia, and malnutrition. ${ }^{2,3}$ Frailty has been associated with an increase from 1.8- to 3-fold in operative mortality risk. ${ }^{4,5}$ Additional insight may be derived from intensive care unit risk models, as well as from assessment of delirium, assessment of mobility, novel biomarkers, and biosensor data. ${ }^{6,7}$

Similarly, dynamic, personalized, risk-mitigation strategies must be used. ${ }^{8}$ The Society of Critical Care Medicine ICU Liberation Campaign has highlighted practices that individually and collectively can help reduce delirium, improve pain management, and reduce long-term adverse consequences for adult intensive care unit patients. Ironically, nutrition, a vital component of recovery after surgery, is not a component in this practice "bundle." In this issue of the Journal, Stoppe and colleagues ${ }^{10}$ appropriately suggest that cardiac surgeons implement the lessons learned from surgical metabolism and nutrition leaders-Cuthbertson, ${ }^{11}$ Dudrick and colleagues, ${ }^{12}$ and others-and institute an investigative and improvement journey.

Unfortunately, change is slow and difficult, and it will not occur with their suggested "be calm" attitude. We therefore suggest a more emotional appeal to our colleagues to

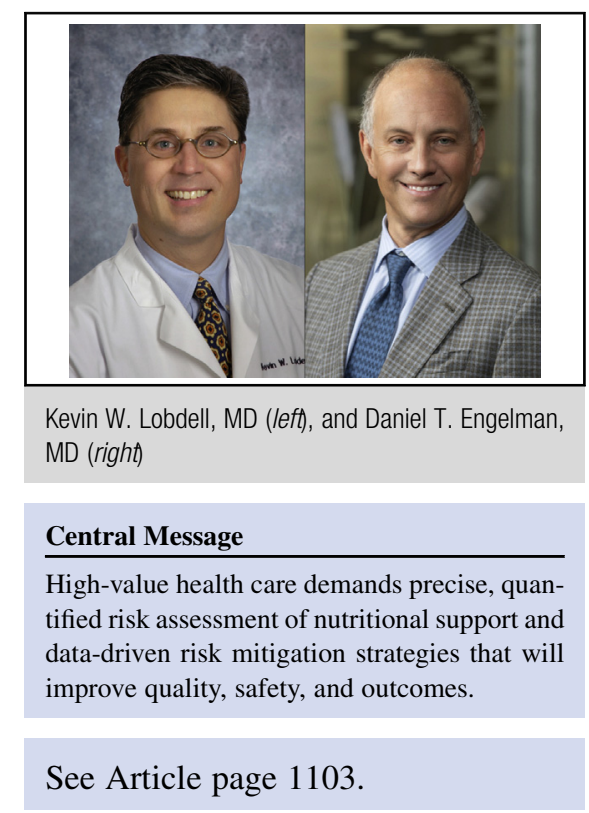

develop data-driven insight through prioritized research and improvement of risk models. Digital health tools, more comprehensive data sets, and intelligent computing are central to transformational solutions to improve quality, safety, and value. ${ }^{13,14}$ The measurement of our success must include long-term follow-up of mortality, morbidity, rate of recovery, quality of life, and the related patient-reported outcome measures. Simply put, transforming health care will require an enhanced understanding of the challenges and problems rather than providing solutions that are based on the limited currently available evidence.

\section{References}

1. Society for Enhanced Recovery after Surgery. The story behind ERAS ${ }^{\circledR}$ Cardiac. Available at: https://www.erascardiac.org/about/eras-cardiac-society. Accessed April 19, 2019.

2. Society of Thoracic Surgeons. Online STS adult cardiac surgery risk calculator. Available at: http://riskcalc.sts.org/stswebriskcalc/. Accessed April 19, 2019.

3. euroSCORE Project. euroSCORE interactive calculator. Available at: http:// www.euroscore.org/calc.html. Accessed April 19, 2019.

4. Lee DH, Buth KJ, Martin BJ, Yip AM, Hirsch GM. Frail patients are at increased risk for mortality and prolonged institutional care after cardiac surgery. Circulation. 2010;121:973-8.

5. Yanagawa B, Graham MM, Afilalo J, Hassan A, Arora RC. Frailty as a risk pre dictor in cardiac surgery: beyond the eyeball test. J Thorac Cardiovasc Surg. 2018; 156:172-6.e2.

6. Hekmat K. Online calculation of the cardiac intensive care score. Available at: http://www.cardiac-icu.org/Online-Calculation.html. Accessed April 19, 2019.

7. Lobdell KW, Parker DM, Likosky DS, Rezaee M, Wyler von Ballmoos M, Alam SS, et al. Preoperative serum ST2 level predicts acute kidney injury after adult cardiac surgery. J Thorac Cardiovasc Surg. 2018;156:1114-23.e2. 
8. Lobdell KW, Rose GA, Mishra AK, Sanchez JA, Fann JI. Decision making, evidence, and practice. Ann Thorac Surg. 2018;105:994-9.

9. Society of Critical Care Medicine. ABCDEF bundle. Available at: https://www. sccm.org/ICULiberation/ABCDEF-Bundles. Accessed April 19, 2019.

10. Stoppe C, Whitlock R, Arora RC, Heyland D. Nutrition support in cardiac surgery patients: be calm and feed on! J Thorac Cardiovasc Surg. 2019; 158:1103-8.

11. Cuthbertson DP. Observations on the disturbance of metabolism produced by injury to the limbs. Q J Med. 1932;25:233-46.
12. Dudrick SJ, Wilmore DW, Vars HM, Rhoads JE. Long-term total parenteral nutrition with growth, development, and positive nitrogen balance. Surgery. 1968;64: $134-42$.

13. Topol EJ. High-performance medicine: the convergence of human and artificial intelligence. Nat Med. 2019;25:44-56.

14. Daskivich TJ, Houman J, Lopez M, Luu M, Fleshner P, Zaghiyan K, et al. Association of wearable activity monitors with assessment of daily ambulation and length of stay among patients undergoing major surgery. JAMA Netw Open. 2019;2:e187673. 